\title{
IMPLEMENTASI DATA MINING TERHADAP PRESTASI BELAJAR MAHASISWA BERDASARKAN PERGAULAN DAN SOSIAL EKONOMI DENGAN ALGORITMA K-MEANS CLUSTERING
}

\author{
Suliman \\ suliman170892@gmail.com \\ STIMIK Bina Bangsa, Kendari, Indonesia
}

\begin{abstract}
Abstrak
Perkembangan teknologi informasi saat ini memungkinkan data dapat disimpan dalam bentuk digital. Pada Perguruan Tinggi jumlah mahasiswa akan terus bertambah seiring berjalannya waktu yang menyebabkan data yang tersimpan terutama data yang berhubungan dengan akademik mahasiswa akan terus bertambah. Data mining merupakan kegiatan yang bertujuan untuk menggali informasi dari tumpukan data yang besar. Data mining merupakan proses analisis data menggunakan perangkat lunak untuk menemukan pola atau aturan tertentu dari sejumlah data dalam jumlah besar yang diharapkan dapat menemukan pengetahuan guna mendukung keputusan. Teknik data mining yang digunakan dalam penelitian ini adalah teknik clustering dengan Algoritma K-Means Clustering dalam proses pengklasifikasian data yang berhubungan dengan akademik mahasiswa untuk dapat mengetahui prestasi dan minat belajar dari mahasiswa yang ada dalam perguruan tinggi. Penelitian ini menghasilkan sebuah model yang dapat digunakan untuk melakukan pengelompokan mahasiswa berdasarkan minat belajarnya sehingga dapat terdeteksi mahasiswa yang bergaul dengan teman yang lebih mengutamakan belajar dan juga dengan status ekonomi yang baik ternyata dapat meningkatkan prestasi belajar mahasiswa.
\end{abstract}

Kata Kunci: Teknologi Informasi, Data mining, K-Means Clustering.

\begin{abstract}
The development of information technology nowadays allows data to be stored in digital form. In Higher Education the number of students will continue to increase over time which causes the data stored, especially data related to student academics, will continue to grow. Data mining is an activity that aims to extract information from large piles of data. Data mining is the process of analyzing data using software to find certain patterns or rules from large amounts of data that are expected to find knowledge to support decisions. The data mining technique used in this research is the clustering technique with the $K$-Means Clustering Algorithm in the process of classifying data related to student academics in order to be able to find out the achievement and interest in learning of students in college. This study produces a model that can be used to group students based on their learning interests so that students who hang out with friends who prioritize learning and with good economic status can actually improve student achievement.
\end{abstract}

Keywords: Information Technology, Data mining, K-Means Clustering.

\section{Pendahuluan}

Perkembangan teknologi informasi terutama yang berhubungan dengan media penyimpanan saat ini berkembang begitu pesat. Media penyimpanan data dapat digunakan oleh sebuah perguruan tinggi untuk menyimpan data yang berhubungan dengan akademik mahasiswa. Data bagi suatu perguruan tinggi sangat bermanfaat jika diolah lebih lanjut untuk menghasilkan sebuah informasi yang dapat digunakan dalam pengambilan keputusan bagi pucuk pimpinan perguruan tinggi tersebut.

Sektor pendidikan harus dijadikan prioritas utama dalam sebuah kebijakan suatu negara. Pendidikan tidak hanya memberikan pengertian akan sesuatu, tetapi juga memberikan pengembangan kepribadian, menanamkan nilai moral, pengetahuan dan keahlian. Seiring dengan berjalannya waktu, data dalam sebuah perguruan tinggi akan terus bertambah sehingga akan menjadi tumpukan data yang menggunung. Jika tidak dikelola dengan baik maka data tersebut hanya berupa data yang tidak ada manfaatnya. Data merupakan hal yang sangat penting dalam melakukan penelitian karena dalam sebuah penelitian selalu melibatkan pengolahan dan analisa data. 
Data merupakan sumber utama yang dapat dimanfaatkan untuk menghasilkan informasi. Informasi begitu penting bagi sebuah perguruan tinggi untuk dapat tetap bertahan dalam menghasilkan lulusan yang terbaik. Pengolahan data yang maksimal maka akan menghasil informasi yang berkualitas. Data mining memungkinkan pemakai menemukan pengetahuan dalam data database yang tidak mungkin diketahui keberadaanya oleh pemakai. Teknik data mining digunakan untuk memeriksa basis data berukuran besar sebagai cara untuk menemukan pola yang baru dan berguna. Tidak semua pekerjaan pencarian informasi dinyatakan sebagai data mining.

Berdasarkan fenomena inilah maka akan dilakukan sebuah penelitian yang bertujuan untuk membuat sebuah model Data mining yang dapat digunakan untuk melakukan pengelompokan mahasiswa berdasarkan pergaulan dan sosial ekonomi dalam peningkatan prestasi belajar mhasiswa. Data yang digunakan dalam penelitian ini adalah data Mahasiswa Program Studi Sistem Informasi dan Program Studi Sistem Komputer STMIK Bina Bangsa Kendari angkatan 2017 dan Teknik Data mining yang digunakan yaitu Clustering.

\section{Metode}

\subsection{Metode Pengumpulan Data}

Metode pengumpulan data yang digunakan dalam penelitian ini adalah pengamatan (observasi), wawancara (interview) dan studi pustaka.

\subsection{Karakteristik Data Warehouse}

Karakteristik data warehouse terdiri dari:

1) Berorientasi Subjek

Data warehouse berorientasi pada subjek dan biasanya subjek tersebut meliputi: pelanggan, produk, transaksi atau kegiatan, kebijakan, klaim dan pengguna. Setiap subjek utama secara fisik diimplementasikan sebagai serangkaian tabel yang terkait di data warehouse.

2) Integrasi

Dari semua aspek data warehouse, integrasi merupakan karakteristik yang paling penting. Dalam integrasi, data disuplai dari beberapa sumber yang berbeda ke dalam data warehouse. Pada integrasi data pada sumber diubah, diformat ulang, dirangkum dan sebagainya sesuai dengan kebutuhan data warehouse.

Data yang dimasukkan ke dalam data warehose adalah data yang memiliki konsistensi. Sehingga data pada tingkat aplikasi atau data sumber yang tidak memiliki konsistensi akan dibatalkan. Contohnya adalah penyimpanan data pada jenis kelamin. Jenis data pada jenis kelamin adalah pria dan wanita. Akan tetapi pada prakteknya format data dapat berupa $\mathrm{p} / \mathrm{l}$ atau $1 / 0$ atau $\mathrm{p} / \mathrm{w}$ dan lain sebagainya. Perbedaan format penamaan pada jenis kelamin tersebut harus dikonversi menjadi sebuah format yang sama. Sehingga data yang dipindahkan ke dalam data warehouse konsisten. Konsistensi data berlaku untuk semua, seperti konversi penamaan, struktur kunci, pengukuran atribut, dan karakteristik fisik data.

3) Non Volatile

Data diperbaharui atau diubah dalam lingkungan operasional merupakan hal yang biasa. Namun data pada data warehouse memilili karakteristik yang berbeda. Data warehouse dapat dimuat dan diakses tetapi tidak dapat diperbaharui. Maksudnya adalah data tidak dapat diubah, dihapus atau ditambah.

4) Time Variant

Time Variant atau rentang waktu menyiratkan bahwa setiap unit data dalam data warehouse akurat pada beberapa waktu. Dalam beberapa kasus, record ditandai oleh waktu. Dalam kasus lain, record memiliki tanggal transaksi. Tapi dalam setiap kasus, ada beberapa bentuk penandaan waktu untuk menunjukkan waktu selama record data akurat . 


\subsection{Data Mining}

Menurut [1] data mining (DM) adalah gabungan sejumlah disiplin ilmu computer (ACM2006), yang mendefinisikan sebagai proses penemuan pola-pola baru dari kumpulan-kumpulan data sangat besar, meliputi metode-metode yang merupakan irisan dari artificial intelligence, machine learning, statistic dan database systems (ACM 2006). Data mining atau penambahan kata adalah teknik yang relatif cepat dan mudah untuk menemukan pola dan/atau relasi antar data, secara otomatis. Dengan menggabungkan empat disiplin ilmu komputer seperti definisi diatas, pengetahuan bisa ditemukan dalam lima proses berurutan: seleksi, pemprosesan, transformasi, data mining, dan interprestasi/evaluasi.

Dari definisi diatas, maka dapat disimpulkan bahwa secara umum data mining adalah suatu kegiatan analisa data untuk mencari suatu pola tertentu, dengan jumlah data yang besar dan bertujuan utuk menghasilkan informasi yang dapat digunakan dan dikembangkan lebih lanjut.

Data mining merupakan inti dari proses Knowledge Discovery Databases (KDD), meliputi dugaan algoritma yang mengeksplor data, membangun model dan menemukan pola yang belum diketahui. KDD merupakan penyelesaian masalah dengan menganalisa data yang ada pada database dengan data tersimpan secara elektronik dan pencariannya dilakukan otomatis seperti pada computer.

Tahapan pada proses KDD pada database menurut [2] seperti pada Gambar 1 dibawah ini :

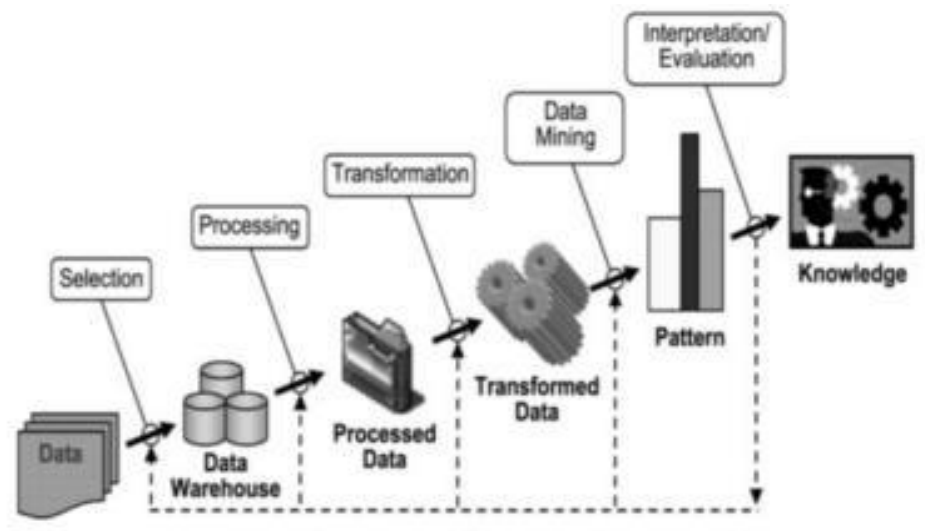

1. Data Selection

Gambar 1. Tahapan proses KDD

Pemilihan (seleksi) data dari sekumpulan data operasional perlu dilakukan sebelum tahap penggalian informasi dalam KDD dimulai. Data hasil seleksi yang akan digunakan untuk proses data mining, disimpan suatu berkas, terpisah dari basis data operasional.

2. Pre-processing/Cleaning

Sebelum proses data mining dapat dilaksanakan, perlu dilakukan proses cleaning pada data yang menjadi fokus KDD. Proses cleaning mencakup antara lain membuang duplikasi data, memeriksa data yang inkonsisten, memperbaiki kesalahan pada data, seperti kesalahan cetak (tipografi). Juga dilakuakan proses enrichment, yaitu proses "memperkaya" data yang sudah ada dengan data atau informasi yang relevan dan diperlukan untuk KDD, seperti data atau informasi eksternal.

\section{Transformation}

Coding adalah proses transformasi pada data yang telah dipilih, sehingga data tersebut sesuai untuk proses data mining. Proses coding dalam KDD merupakan proses kreatif dan sangat tergantung pada jenis atau pola informasi yang akan dicari dalam basis data.

4. Data Mining

Data mining adalah proses mencari pola atau informasi menarik dalam data terpilih dengan menggunakan teknik atau metode tertentu. Teknik, metode, atau algoritma dalam data mining sangat bervariasi pemilihan metode atau algoritma yang tepat sangat bergantung pada tujuan dan proses KDD secara keseluruhan. 
5. Interpretation/ Evaluation

Pola informasi yang dihasilkan dari proses data mining, perlu ditampilkan dalam bentuk yang mudah dimengerti oleh pihak yang berkepentingan. Tahap ini merupakan bagian dari proses KDD yang disebut interpretation. Tahap ini mencakup pemeriksaan apakah pola atau informasi yang ditemukan bertentangan dengan fakta atau hipotesa yang ada sebelumnya. Langkah terakhir KDD adalah mempresentasikan pengetahuan dalam bentuk yang mudah dipahami pengguna.

\subsection{Clustering}

Clustering merupakan suatu teknik data mining yang mengelompokkan data ke dalam beberapa kelompok (grup atau cluster atau segmen) yang tiap cluster dapat ditempati beberapa anggota bersamasama. Pada dasarnya clustering merupakan suatu metode untuk mencari dan mengelompokkan data yang memiliki kemiripan karakteristik (similarity) antara satu data dengan data yang lain. Clustering merupakan salah satu metode data mining yang bersifat tanpa arahan (unsupervised), maksudnya metode ini diterapkan tanpa adanya latihan (training) dan tanpa ada guru (teacher) serta tidak memerlukan target output. Dalam data mining ada dua jenis metode clustering yang digunakan dalam pengelompokan data, yaitu hierarchical clustering dan non-hierarchical clustering.

Hierarchical clustering adalah suatu metode pengelompokan data yang dimulai dengan mengelompokkan dua atau lebih objek yang memiliki kesamaan paling dekat. Kemudian proses diteruskan ke objek lain yang memiliki kedekatan kedua. Demikian seterusnya sehingga cluster akan membentuk semacam pohon dimana ada hierarki (tingkatan) yang jelas antar objek, dari yang paling mirip sampai yang paling tidak mirip. Secara logika semua objek pada akhirnya hanya akan membentuk sebuah cluster.

Berbeda dengan metode hierarchical clustering, metode non-hierarchical clustering justru dimulai dengan menentukan terlebih dahulu jumlah cluster yang diinginkan (dua cluster, tiga cluster, atau lain sebagainya). Setelah jumlah cluster diketahui, barulah proses cluster dilakukan tanpa mengikuti proses hierarki. Metode ini biasa disebut dengan K-Means Clustering. Definisi K-Means merupakan salah satu metode data clustering non-hirarki yang mengelompokan data dalam bentuk satu atau lebih cluster/kelompok. Data-data yang memiliki karakteristik yang sama dikelompokan dalam satu cluster/kelompok dan data yang memiliki karakteristik yang berbeda dikelompokan dengan cluster/kelompok yang lain sehingga data yang berada dalam satu cluster/kelompok memiliki tingkat variasi yang kecil [3].

\subsection{Metode Analisis K-Means}

Dalam statistic dan mesin pembelajaran, pengelompokan K-Means merupakan metode analisis kelompok yang merngarah pada pemartisian $\mathrm{N}$ objek pengamatan ke dalam K kelompok (cluster) dimana setiap objek pengamatan dimiliki oleh sebuah kelompok dengan mean (rata-rata) terdekat, mirip dengan algoritma Expectation-Maximization untuk Gaussian Mixture dimana keduanya mencoba untuk menemukan pusat dari kelompok dalam data sebanyak literasi perbaikan yang dilakukan oleh kedua algoritma. Pengelompokan data dengan metode K-Means ini secara umum dilakukan dengan langkah berikut [4].

1) Tentukan jumlah kelompok.

2) Alokasikan data ke dalam kelompok secara acak.

3) Hitung pusat kelompok (sentroid/rata-rata) dari data yang ada di masing-masing kelompok.

4) Alokasikan masing-masing data ke sentroid/rata-rata tersebut

5) Kembali ke langkah 3, jika masih ada data yang berpindah kelompok, atau ada perubahan nilai sentroid diatas nilai ambang yang ditentukan, atau apabila perubahan nilai pada fungsi objektif yang digunakan masih diatas nilai ambang yang ditentukan.

\subsection{Pergaulan}

Pergaulan memiliki pengaruh dalam membentuk suatu komponen kepribadian seseorang, pergaulan yang dilakukan oleh seseorang tanpa disadari akan membentuk dirinya, menyerupai lingkungan 
bergaulnya. Jadi kepribadian seseorang dapat dilihat dari pergaulannya, apakah pergaulan yang positif atau pergaulan yang negatif [5]. Pergaulan memiliki ragam pola yang terarah serta ragam pola yang tidak terarah.

Ragam pola terarah merupakan pergaulan yang memiliki pola positif yaitu kearah lingkungan yang baik serta tidak melanggar peraturan yang berlaku di masyarakat dan membawa pengaruh positif. Misalnya kerjasama atau gotong royong membersihkan lingkungan atau membentuk komunitas gemar membaca. Sedangkan ragam pola tidak terarah adalah pergaulan yang memiliki pola negatif biasanya identik dengan sesuatu yang bebas dan tanpa aturan. Biasanya pergaulan ini sering dilakukan oleh remaja dan melanggar peraturan yang ada di masyarakat.

\subsection{Faktor Sosial Ekonomi}

Sosial ekonomi adalah segala sesuatu hal yang berhubungan dengan tindakan pemenuhan kebutuhan masyarakat, keadaan sosial ekonomi orang berbeda-beda. Ada yang memiliki sosial ekonomi yang rendah dan ada pula yang memiliki sosial ekonomi yang tinggi. Keadaan sosial ekonomi dapat juga dikatakan sebagai suatu keadaan atau kedudukan yang di atur secara sosial dan menetapkan seseorang di suatu posisi tertentu, misalnya pemberian pekerjaan .

Terdapat beberapa variabel yang sering digunakan sebagai indikator untuk mengukur status sosial ekonomi antara lain pekerjaan, pendapatan, dan tingkat pendidikan [6]. Ukuran atau kriteria yang dipakai untuk menggolongkan anggota masyarakat ke dalam kelas tertentu adalah kekayaan, kekuasaan/jabatan, kehormatan, dan pendidikan/ ilmu pengetahuan.

Pada status sosial ada beberapa kriteria yang biasa dipakai untuk menggolongkan anggota masyarakat/keluarga ke dalam suatu lapisan [7].

1. Ukuran kekayaan, Lapisan masyarakat teratas merupakan yang memiliki kekayaan paling banyak.

2. Ukuran kekuasaan, Barang siapa memiliki kekuasaan atau memiliki wewenang terbesar menempati lapisan atas.

3. Ukuran kehormatan, Orang yang paling disegani memiliki tempat teratas, ukuran ini terlepas dari jumlah kekayaan dan kekuasaan. Hal ini banyak dijumpai dalam masyarakat tradisional.Biasanya adalah orang tua, dan yang pernah berjasa.

\section{Hasil Dan Pembahasan}

Untuk melakukan data mining terhadap data maka dibutuhkan beberapa tabel. Tabel ini dalam database sebenarnya sudah ada, namun tabel yang dibuat ini lebih kecil, karena hanya terdiri dari fieldfield yang diperlukan untuk proses Data mining saja. Rancangan terhadap database yang akan digunakan untuk proses dijelaskan di bawah ini.

\subsection{Rancangan Database}

Database yang dirancang dalam penelitian ini terdiri dari beberapa tabel. Tabel-tabel dalam rancangan dapat diuraikan sebagai berikut:

1) Tabel Mahasiswa (tb_mhs)

Tabel ini digunakan untuk menampung data-data pribadi mahasiswa. Adapun atribut (field) dapat diuraikan sebagai berikut:

Tabel 1. Tabel Mahasiswa

\begin{tabular}{llc}
\hline Nama & Type & Width \\
\hline nim* & varchar & 9 \\
nama & varchar & 40 \\
jenis_kelamin & varchar & 2 \\
temp_tgl_lahir & date & 50 \\
kd_prodi & varchar & 3 \\
alamat & varchar & 250 \\
asal_sek & varchar & 20 \\
Penghasilan_ortu & varchar & 20 \\
\hline
\end{tabular}


Jurnal Sistem Informasi dan Sistem Komputer,Vol.6, No.1, Januari 2021

ISSN: $2715-906 \mathrm{X}$ (Online)

doi) $10.51717 /$ simkom.v6i1.48

2) Tabel hasil nilai (tb_nilai)

Tabel 2. Tabel hasil nilai

\begin{tabular}{llr}
\hline Nama & Type & Width \\
\hline Nim* & varchar & 9 \\
tugas & int & 3 \\
kehadiran & Int & 6 \\
latihan & int & 6 \\
Uts & int & 6 \\
uas & int & 6 \\
nilai_angka & int & 6 \\
nilai_huruf & varchar & 1 \\
\hline
\end{tabular}

\subsection{Seleksi Data (Data Selection)}

Sumber data yang digunakan dalam penelitian berasal dari data mahasiswa angkatan 2017 pada Program Studi Sistem Informasi dan Program Studi Sistem Komputer. Beberapa jenis data diperoleh dari sistem yang berjalan yang digunakan untuk penelitian, indikator penentu dalam pengelompokan data keluaran yang diinginkan.

1) Data Mahasiswa (tb_mhs)

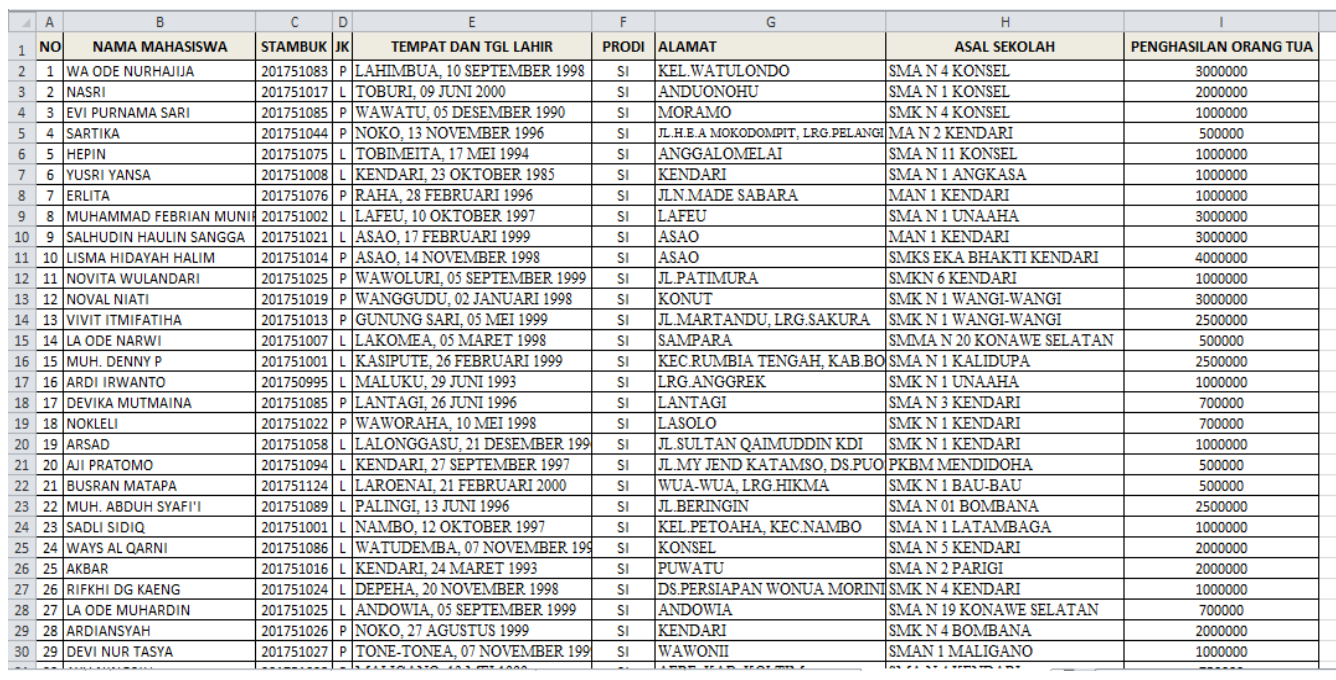

(Sumber: pengolahan data mahsiswa STMIK Bina Bangsa Kendari)

Gambar 2. Data Mahasiswa

2) Data Nilai (tb_nilai)

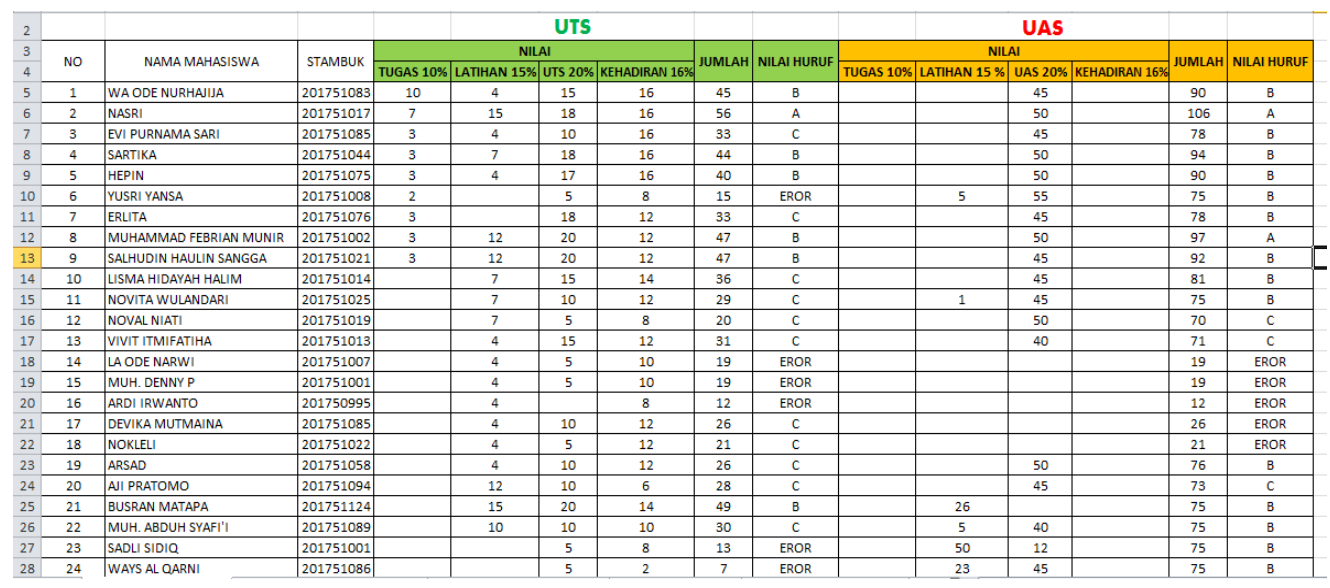

(Sumber: pengolahan data nilai mahsiswa STMIK Bina Bangsa Kendari)

Gambar 3. Data Nilai 
Jurnal Sistem Informasi dan Sistem Komputer,Vol.6, No.1, Januari 2021

ISSN: 2715-906X (Online)

doi) $10.51717 /$ simkom.v6i1.48

\subsection{Praproses Data}

\subsubsection{Pembersihan Data (Data Cleaning)}

Tahap kedua pada proses Data mining adalah cleaning data yaitu melakukan pembersihan data terhadap noise yang ditemukan berupa missing value, inkonsisten data, dan redundant data.

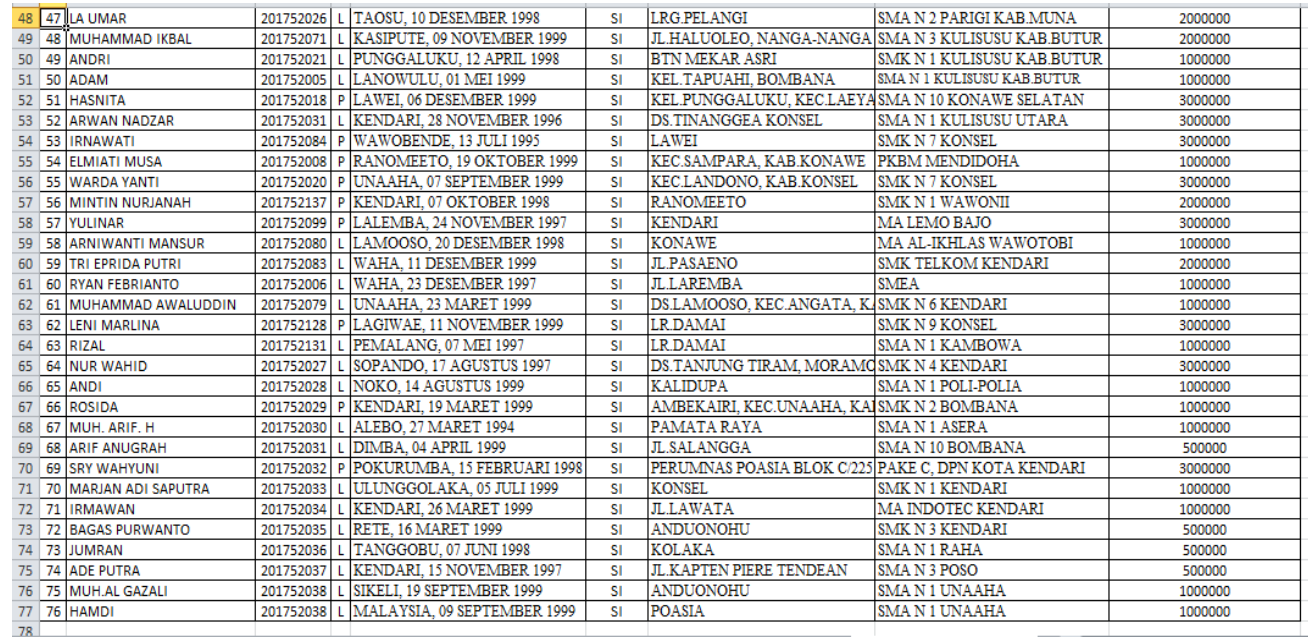

Gambar 4. Proses cleaning data

Pada gambar di atas merupakan hasil proses data yang sudah di cleaning, sehingga sudah tidak ada lagi data yang missing value. Hal ini dilakukan karena data yang missing value tidak memberikan informasi apapun jika dipertahankan keberadaannya. Tahapan proses cleaning data atau disebut juga filter data dari perancangan tb_mhs, tb_khs dan tb_mk. Dari tahap cleaning data yang telah dilakukan diatas diperoleh jumlah data pada tb_mhs sebanyak 76 record.

\subsubsection{Integrasi Data}

Tahap ketiga pada proses data mining adalah tahap integrasi data yaitu penggabungan data dengan tujuan memindahkan seluruh data yang telah di cleaning menjadi satu tabel. Pada tahap ini dari tiga tabel akan di integrasikan untuk mendapatkan data source mahasiswa dan data source jumlah nilai keseluruhan. Untuk mendapatkan data source mahasiswa proses penggabungan data dilakukan dengan merelasikan table pergaulan, tabel pendapatan orang tua atau mahasiswa dan table nilai prestasi belajar mahasiswa matakuliah sistem operasi. Hasil dari integrasi atau join antar tabel diatas maka didapat data source mahasiswa, seperti pada gambar berikut.

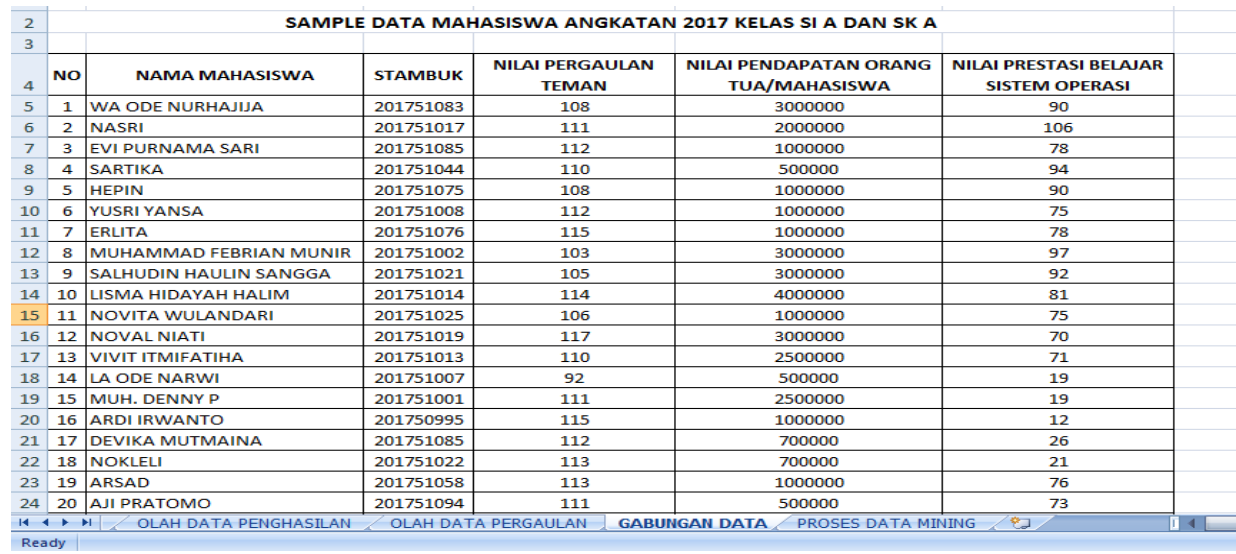

Gambar 5. Integrasi Data

\subsubsection{Tranformasi Data}

Tahap keempat pada proses Data mining adalah tahap tranformasi data yaitu data diubah menjadi bentuk yang sesuai untuk diproses dalam Data mining. Dalam penelitian ini data yang akan diproses dari database mysql untuk digunakan di tool SSIS maka format tersebut diubah menjadi mdf. 
Jurnal Sistem Informasi dan Sistem Komputer,Vol.6, No.1, Januari 2021

ISSN: $2715-906 \mathrm{X}$ (Online)

$10.51717 /$ simkom.v6i1.48

3.4 Sosial Ekonomi Keluarga

1) Pendidikan orang tua

Berdasarkan hasil analisis, rata-rata pendidikan orang tua yaitu SD. Rincian tentang pendidikan orang tua dapat dilihat pada tabel berikut ini.

Tabel 3. Pendidikan orang tua

\begin{tabular}{cccccc}
\hline NO & $\begin{array}{c}\text { Jenjang } \\
\text { pendidikan }\end{array}$ & Ayah & presentasi & Ibu & Presentasi \\
\hline 1 & Tidak sekolah & 7 & 9,2 & 2 & 2,6 \\
2 & SD & 44 & 57,9 & 25 & 32,9 \\
3 & SMP & 10 & 13,2 & 20 & 26,3 \\
4 & SMA & 11 & 14,5 & 20 & 26,3 \\
5 & Diploma & 1 & 1,3 & 2 & 2,6 \\
6 & Sarjana & 3 & 3,9 & 7 & 9,2 \\
& Total & 76 & 100 & 76 & 100 \\
\hline
\end{tabular}

Perbandingan antara latar belakang pendidikan ibu dengan ayah terlihat bahwa latar belakang pendidikan ibu lebih tinggi dari pada pendidikan ayah. Jumlah ibu dari mahasiswa yang sarjana sebanyak 7 orang sedangkan ayah sebanyak 3 orang dan diploma sebanyak 1 orang ayah dan 2 orang ibu. Jenjang pendidikan ayah lebih banyak tamatan SD yaitu 44 orang sedangkan ibu lebih merata yaitu SMP 20 orang dan SMA 20 orang dan SD sebanyak 25 orang.

2) Pekerjaan orang tua

Pekerjaan yang paling banyak adalah petani, baik pekerjaan orang tua perempuan maupun orang tua laki-laki. Sebanyak 37 orang atau 48,7 persen ibu dan 52 orang atau 68,4 persen ayah bekerja sebagai petani. Walaupun daerah Mentawai berupa kepulauan namun dari data yang diperoleh hanya satu orang atau 1,3 persen yang bekerja sebagai nelayan baik orang tua laki-laki maupun orang tua perempuan.Hal ini menjadi perhatian penulis tentang bagaimana pendidikan untuk anak-anak nelayan.Hasil analisis deskriptif frekuensi untuk variabel pekerjaan orang tua mahasiswa Mentawai dapat dilihat pada tabel berikut ini:

Tabel 4. Pekerjaan Orang Tua Mahasiswa

\begin{tabular}{cccccc}
\hline NO & Pekerjaan & Ibu & presentasi & Ayah & Presentasi \\
\hline 1 & Ibu rumah tangga & 18 & 23,7 & 0 & 0 \\
2 & Petani & 37 & 48,7 & 25 & 68,4 \\
3 & Nelayan & 1 & 1,3 & 1 & 1,3 \\
4 & Pedagang & 8 & 10,5 & 5 & 6,6 \\
5 & Wiraswasta & 5 & 6,6 & 9 & 11,8 \\
6 & Pegawai Negeri & 5 & 6,6 & 7 & 9,2 \\
7 & Pegawai swasta & 1 & 1,3 & 1 & 1,3 \\
8 & Lainya & 1 & 1,3 & 1 & 1,3 \\
& Total & 76 & 100 & 76 & 100 \\
\hline
\end{tabular}

3. Kebutuhan Kuliah Biaya konsumsi per bulan Tabel berikut ini mendeskripsikan tentang kebutuhan kuliah mahasiswa di Provinsi Sulawesi Tenggara.

Tabel 5. Biaya Konsumsi Mahasiswa

\begin{tabular}{cccc}
\hline NO & Biaya Konsumsi & Frekuensi & Presentasi \\
\hline 1 & Kurang dari Rp 299.000 & 10 & 13,2 \\
2 & Rp 300.000 - Rp 399.000 & 23 & 30,3 \\
3 & Rp 400.000 - Rp 499.000 & 15 & 19,7 \\
4 & Rp 500.000 - Rp 599.000 & 19 & 25 \\
5 & Rp 600.000 - Rp 699.000 & 2 & 2,6 \\
6 & Rp 700.000 - Rp 799.000 & 2 & 2,6 \\
7 & Rp 700.000 - Rp 799.000 & 5 & 6,6 \\
& Total & 100 & 100 \\
\hline
\end{tabular}


Jurnal Sistem Informasi dan Sistem Komputer,Vol.6, No.1, Januari 2021

ISSN: $2715-906 \mathrm{X}$ (Online)

do) $10.51717 /$ simkom.v6i1.48

\subsection{Status Pergaulan Teman Mahasiswa}

Proses pengambilan data pergaulan teman mahasiswa diambil dari Quisioner yang dibagikan dengan jumlah pertanyaan terkait pergaulan sebanyak 25 pertanyaan dan data yang akan diclusterkan adalah jumlah dari hasil jawaban quisioner, dengan nilai jawaban sebagai berikut:

$\begin{array}{ll}\text { STS } & \text { : Sangat Tidak Sesuai (1) } \\ \text { TS } & \text { :Tidak Sesuai (2) } \\ \text { N } & \text { : Netral (3) } \\ \text { S } & \text { : Sesuai (4) } \\ \text { SS } & \text { : Sangat Sesuai (5) }\end{array}$

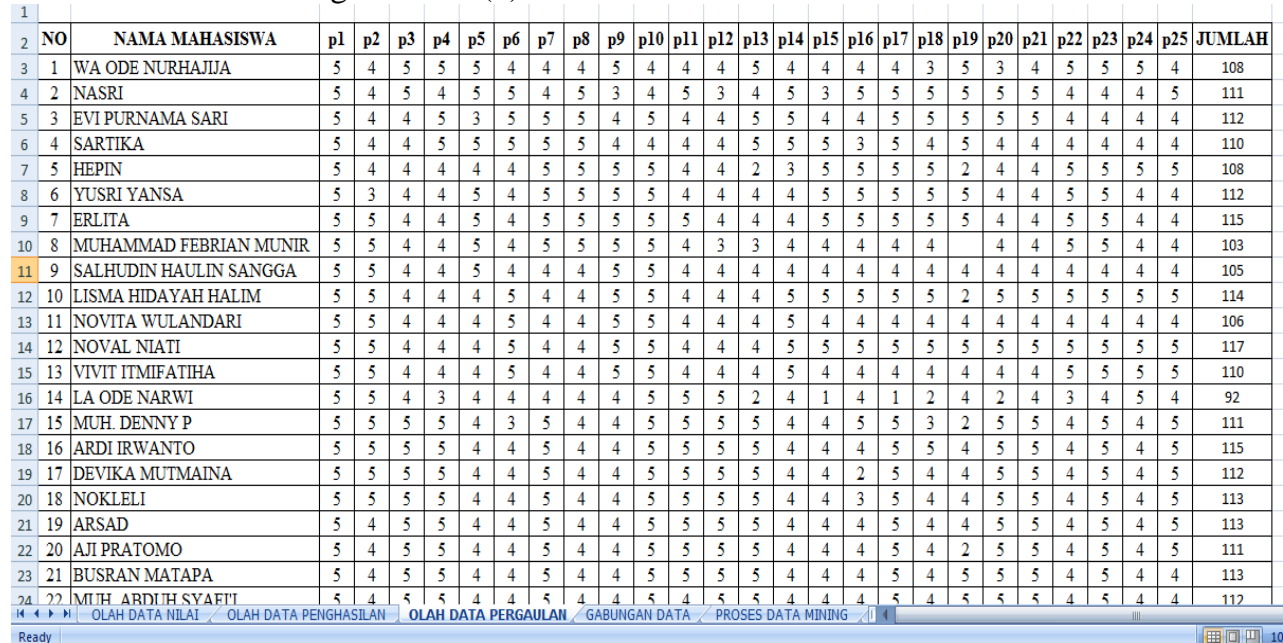

(Sumber : Hasil Perhitungan jawaban Quisioner mahasiswa STMIK Bina Bangsa Kendari ) Gambar 6. Hasil quisioner

\subsection{Proses Data Mining}

Setelah melakukan proses transformasi data, maka akan dilanjutkan ke proses selanjutnya yaitu proses mining data. Data mining merupakan proses mencari pola atau informasi menarik dalam data yang terpilih dengan menggunakan teknik atau metode tertentu. Pemilihan teknik dan algoritma yang tepat sangat bergantung pada proses KDD secara keseluruhan. Pada penelitian ini penerapan data mining menggunakan teknik clustering dan algoritma K-Means, Sebagai berikut;

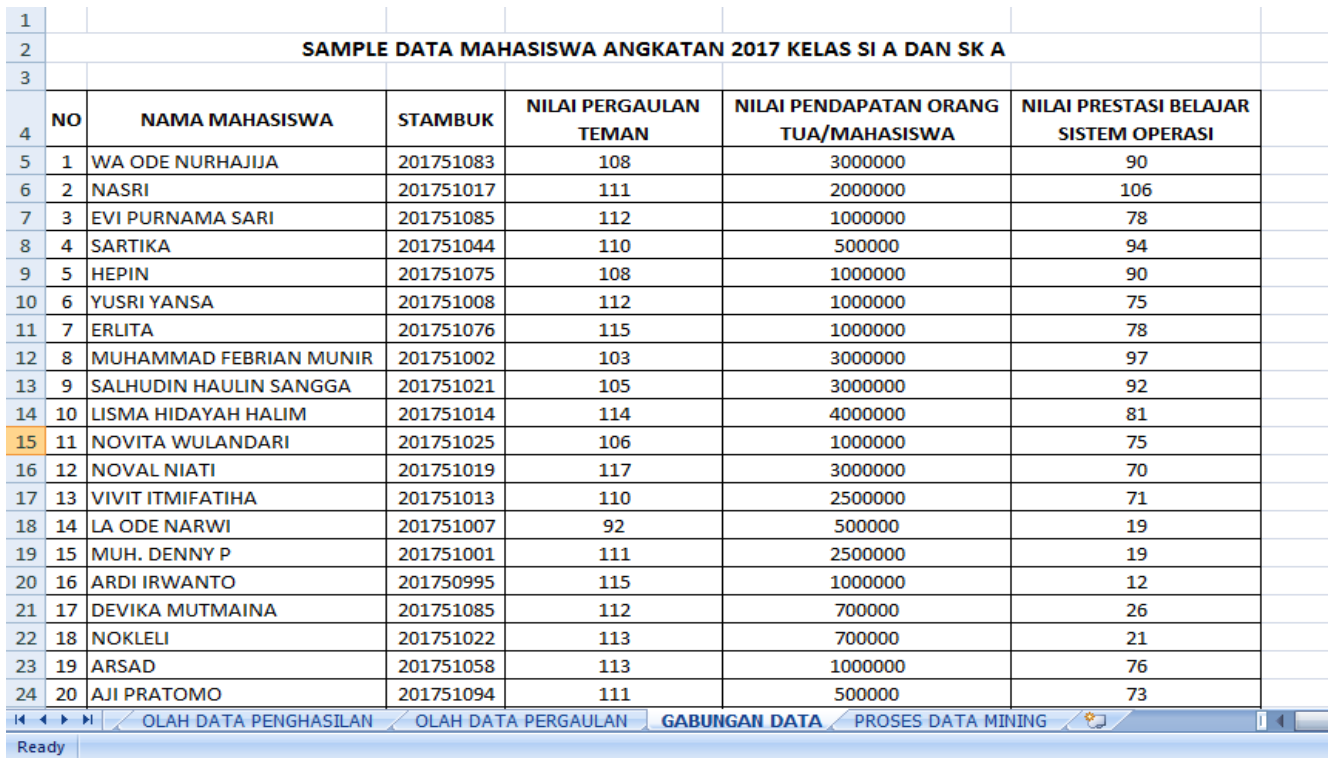

Gambar 7. Hasil clustering data 
Proses Clustering menggunakan aplikasi Rapid Miner menjadi 3 Cluster dimana cluster 2 mendapatkan hasil sangat baik dibuktikan dengan pergaulan yang sangat baik dan status ekonomi sangat baik, cluster 0 mendapatkan hasil baik sedangkan cluster 1 menghasilkan nilai kurang baik, dengan representasi sebgai berikut;

1. Pergaulan $>=112$ sangat baik, $>=100$ baik dan $<100$ kurang baik.

2. Status ekonomi $>=3.000 .000$ menengah atas, $>=2.000 .000$ menengah, $<2.000 .000$ menengah kebawah.

3. Nilai Mahasiswa $>=95$ sangat memuaskan, $>=80$ memuaskan, $<80$ kurang memuaskan.

Dengan hasil sebagai berikut;

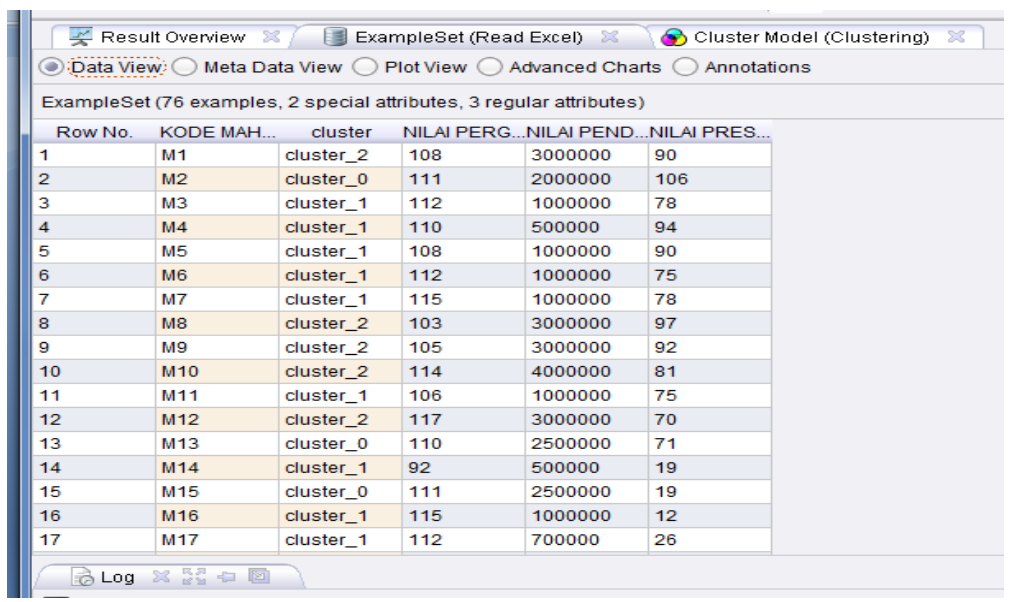

Gambar 8. Hasil clustering rapid miner

Hasil grafik Centroid Plat View sebagai berikut, cluster 2 warna merah menunjukan grafik tertinggi dengan penghasilan diatas 3 juta, cluster 0 warna biru mendapatkan nilai sedang dan cluster 1 dengan hasil paling rendah:

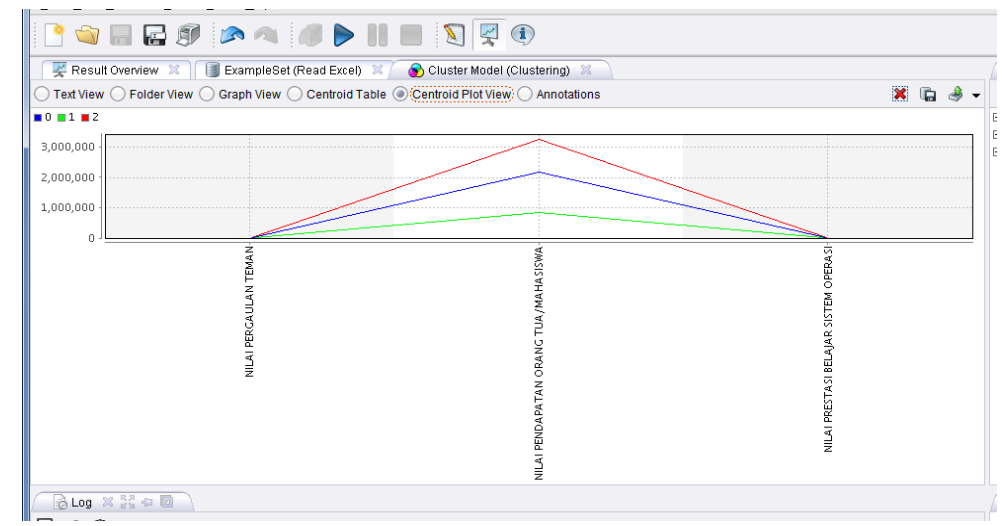

Gambar 9. Hasil Centroid Plat View

Jumlah data yang dicluster sebanyak 76 dengan cluster model, cluster 2 sebanyak 17 item, cluster 0 sebanyak 17 item sedangkan cluster 1 sebanyak 42 item.

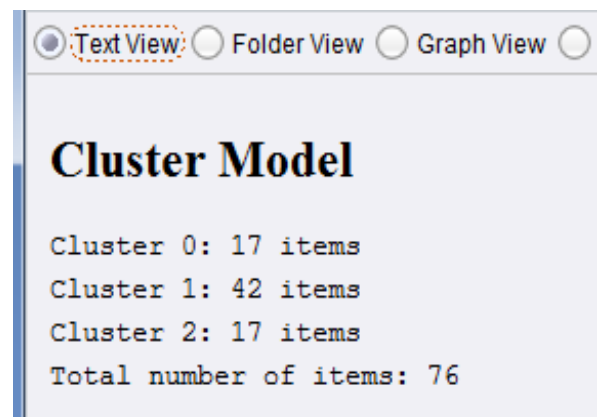

Gambar 10. Text View Cluster Model 


\section{Kesimpulan dan saran}

\subsection{Kesimpulan}

Berdasarkan hasil penelitian dan pembahasan yang telah dijelaskan dapat disimpulkan bahwa perancangan dan Implementasi Aplikasi data mining untuk mengelompokan prestasi belajar mahasiswa didasarkan pada status ekonomi keluarga sangat berpengaruh khususnya jika kuliah dibidang komputer. Mahasiswa secara tidak langsung membutuhkan Komputer dan peralatan lainya untuk menunjang kebutuhan kuliah agar tidak ada kendala dalam proses belajarnya, oleh karena itu status ekonomi sangat berpengaruh dan juga pergaulan dengan kelompok mahasiswa yang lebih mementingkan belajar dibandingkan kegiatan lainnya yang tidak bermanfaat bagi prestasi belajar mahasiswa. Oleh sebab itu bergaul dengan teman mahasiswa yang rajin belajar juga status ekonomi dapat mempengaruhi prestasi belajar mahasiswa.

\subsection{Saran}

Berdasarkan data hasil penelitian dan pembahasan yang telah dikemukakan maka peneliti dapat memberikan saran-saran sebagai berikut:

1. Bagi mahasiswa

Lingkungan pergaulan teman memiliki peranan dalam meningkatkan hasil belajar, mahasiswa diharapkan lebih selektif dalam memilih pergaulan teman sehingga dapat mendukung kegiatan pembelajaran dan mahasiswa tidak terpengaruh hal-hal negatif yang dapat merugikan diri sendiri terutama terkait dengan hasil belajar mahasiswa.

2. Bagi peneliti selanjutnya

Untuk penelitian selanjutnya dapat dilakukan dengan data yang lebih banyak dan parameter yang lebih banyak lagi, sehingga memungkinkan mendapatkan metode dan fokus penelitian jangan hanya pada pergaulan teman dan status ekonomi yang tentunya dapat meningkatkan prestasi belajar mahasiswa.

3. Gunakan metode yang lain atau lebih dari satu metode dengan harapan mendapatkan parameter hasil yang lebih baik dalam peningkatan belajar mahasiswa sehingga nantinya dapat dijadikan referensi dosen dalam meningkatkan kualitas mahasiswa.

\section{Daftar Pustaka}

[1] S. M. Dr. Suyanto, Data Mining Untuk Klasifikasi Dan Klasterisasi Data. Bandung: Informatika, 2017.

[2] R. T. Vulandari, "Pengelompokan Tingkat Keamanan Wilayah Jawa Tengah Berdasarkan Indeks Kejahatan Dan Jumlah Pos Keamanan Dengan Metode Klastering K-Means," J. Ilm. SINUS, vol. Vol 14, No, no. ISSN :1693-1173, pp. 59-72, 2016.

[3] J. O. Ong, "Implementasi Algotritma K-means clustering untuk menentukan strategi marketing president university," J. Ilm. Tek. Ind., vol. vol.12, no, no. juni, pp. 10-20, 2013.

[4] E. Prasetyo, Data Mining Konsep dan Aplikasi menggunakan MatLab. Yogyakarta: Andi, 2012.

[5] Ilma mulwafa, Psikologi Remaja Terhadap Pergaulan Serta Perkembangan Peserta Didik. Jakarta: PT Bumi Aksara.

[6] T. H. Handoko, Manajemen Personalia dan Sumber Daya Manusia. Yogyakarta: BPFE, 2012.

[7] S. dan S. Soekanto, Sosiologi Suatu Pengantar. Jakarta: Raja Grafindo Persada, 2013. 